\title{
THERMAL ALTERATION DURING ROTARY VERSUS RECIPROCATION ROOT CANAL PREPARATION
}

\author{
RAID F. SALMAN \\ Dept. of Conservative and Prosthodontics, College of Dentistry, University of Duhok, Kurdistan Region- Iraq
}

(Accepted for Publication: August 29, 2019)

\begin{abstract}
Aims and Objectives: Temperature rise may affect on the bone health. The alkaline phosphatase inactivation within the bone has been related with increase of temperatures, around $56{ }^{\circ} \mathrm{C}$. This study assessed the effect of root canal space instrumentation on the temperature elevation on root dentin.

Method: Twenty extracted human teeth had thermocouples adhered to the outer proximal root surface. The temperature elevation was recorded during the root canal preparation. The samples were divided into two groups $(n=10)$, according to the type of root canal preparation motion; rotation or reciprocation.

Results: Data were subjected to a t-test $(\alpha=0.05)$. The rotary preparation was caused the higher temperature alteration $\left(2.6 \pm 0.5^{\circ} \mathrm{C}\right)$ than the reciprocation preparation $\left(1.5 \pm 0.3^{\circ} \mathrm{C}\right)$.

Conclusion: Type of root canal preparation motion had different thermal alteration on root canal surface.
\end{abstract}

\section{INTRODUCTION}

$\mathbf{R}_{\mathrm{r}}$ otary nickel-titanium (Ni-Ti) instruments have got huge improvement in endodontic canal preparation. In addition to being faster, $\mathrm{Ni}$ Ti instruments are known to be more flexible and permit preservation of the preparation to be much tapered and centered, produce lesser iatrogenic errors than stainless steel instruments $(1,2)$. Instruments velocity inside the root canal might produce heat and its transmission to the outer surface since heat is directly proportional to velocity ${ }^{(3)}$. The quantity of heat production that is concluded during the root canal instrumentation has been assessed using different in vitro studies (4-6). However, no studies have measured the temperature alteration on the root dentin external surface in difference between two types of motions; rotation and reciprocation. Therefore, the aim of this study was to test two hypotheses: first, that the temperature rise generated during endodontic treatment differs in each motion; second, that no any difference between them.

\section{MATERIAL AND METHOD}

Twenty freshly extracted human premolars, with single roots anatomically similar in size and shape were collected after measurement of the buccolingual and mesiodistal widths in millimeters, allowing for a maximum deviation of $10 \%$ from the average with single canal. All crowns were removed and sectioned perpendicular to the long axis, $12 \mathrm{~mm}$ from the apex, with a water-cooled diamond disk and the roots were stored in de-ionized distilled water at $37^{\circ} \mathrm{C}$. The samples surfaces were painted with petroleum jelly and the samples were embedded in a selfpolymerizing resin up to the coronal margin. A plastic cylinder $(20 \mathrm{~mm}$ in diameter and $30 \mathrm{~mm}$ long) was placed around the sample and fixed in position with a cyanoacrylate adhesive. The resin was prepared according to the manufacturer's instructions and inserted into the cylinder. The resin cylinder was axially sectioned in a highprecision cutting machine to allow exposure of the proximal root surfaces. Thermocouples were located on the proximal root surface; symmetrically on the external root surface at 2 $\mathrm{mm}$ from cervical region. A metallic fixer was used for an effective fixation of the resin cylinder on the workbench. The device consisted of a rectangular aluminum base with a central slot for positioning the resin cylinder (controlled by a lateral screw) and a lateral slot to grasp the cervical thermocouple. The thermocouple was used for temperature rise measurement is made of iron and constantan alloys $(\mathrm{Cu} 55 \%+\mathrm{Ni} 45 \%)$ represented by two terminals: a positive pole and a negative pole. Externally, the thermocouple was coated with rubber and includes a stainless steel rod (3.0 $\mathrm{mm}$ diameter). The thermocouple can capture temperature variations ranging from $10{ }^{\circ} \mathrm{C}$ to $+600{ }^{\circ} \mathrm{C}$ with a $\pm 0.3{ }^{\circ} \mathrm{C}$ accuracy. The 
lateral slot support on the cylinder apparatus was fixed the thermocouple and kept it in direct contact with the external sample surface. The data were transferred to a computer, using specific acquisition signal transformation by data analysis software.

A single operator calibrated to use the rotary $\mathrm{Ni}-\mathrm{Ti}$ instrumentation and the Pro Taper Next Rotary System and reciprocating Wave One Gold System performed the root canal instrumentations. Two groups of samples of 10 for each randomly distributed for two types of motions of preparation; (rotation by Pro Taper Next single file X2 and reciprocation by Wave One Gold single file "Primary"). The root canals were instrumented at a working length (WL) of $11 \mathrm{~mm}(1 \mathrm{~mm}$ from the apex) with file driven by an electric engine at 300 $\mathrm{rpm}$ with $3 \mathrm{~N} / \mathrm{cm}$ torque in the sequence recommended by the manufacturer for the crowndown technique. Instrumentation was done with copious irrigation with $2 \mathrm{~mL} 2.5 \% \mathrm{NaOCl}$, followed by a final rinse with $10 \mathrm{~mL}$ of the same solution. The irrigation needle was placed as deeply as possible into the root canal. To compare the temperature alteration generated during endodontic procedure, data were analyzed by t-test $(\alpha=0.05)$.

\section{RESULTS}

The mean temperature rise in ${ }^{\circ} \mathrm{C}$ (mean and standard deviation) for the evaluated groups is presented in $\quad$ Table 1.

Table (1): Mean and standard deviation of temperature alteration in ${ }^{\circ} \mathrm{C}$

\begin{tabular}{cccccc}
\hline Groups & $\mathbf{N}$ & Mean & SD & Min. & Max. \\
\hline PTN & 10 & 2.6 & \pm 0.5 & 2.1 & 3.1 \\
\hline WOG & 10 & 1.5 & \pm 0.3 & 1.2 & 1.8 \\
\hline
\end{tabular}

From Table 1; it is obvious that rotary instrumentation with PTN file had higher temperature rise by mean of $\left(2.6 \pm 0.5^{\circ} \mathrm{C}\right)$ over reciprocation instrumentation with WOG file $\left(1.5 \pm 0.3^{\circ} \mathrm{C}\right)$. By use t-test inferential statistics; there was significant difference with in favor of reciprocation at $(\mathrm{p}<0.05)$ (Table 2; Fig. 1).

Table (2): t-test for difference in temperature alteration in ${ }^{\circ} \mathrm{C}$

\begin{tabular}{cccccc}
\hline Pair & $\mathbf{N}$ & Mean & df & t-test & $\mathbf{P}$ \\
\hline PTN-WOG & 20 & 1.9 & 18 & -0.253 & 0.02 \\
\hline
\end{tabular}




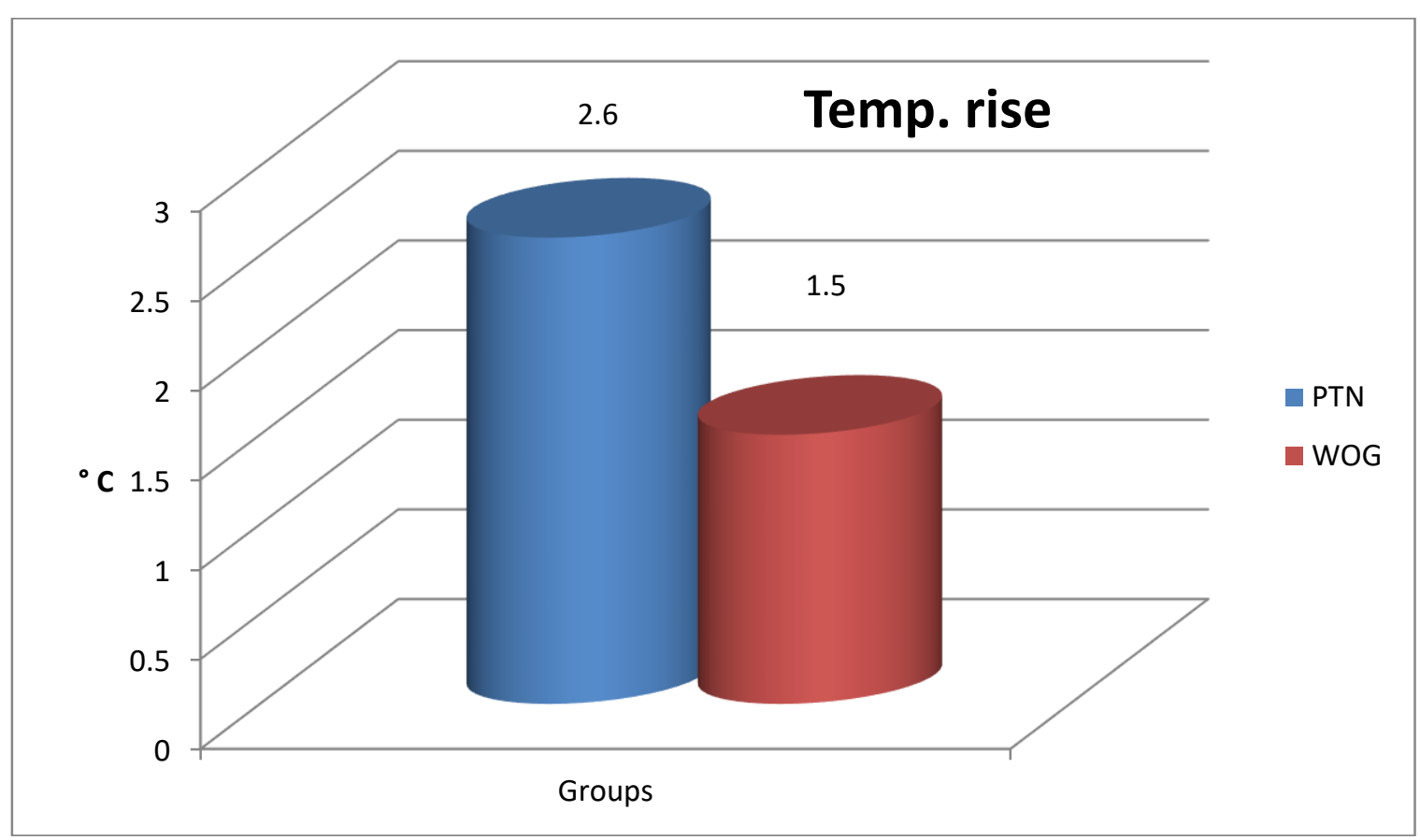

Fig. (1): Bar chart for difference in temperature alteration in ${ }^{\circ} \mathrm{C}$

\section{DISCUSSION}

Thermal analysis of endodontic debridement on root dentin is some what complicated procedure when the required data must be measured in different conditions. Methods that were less destructive, such as the external sample surface temperature alteration using thermocouples, concluded that it is might be possible; and heat elevation can be a quantity at end result. Thermocouples action was based on the thermoelectric scenario, which results in an electric current when two dissimilar metal wires are united together and got temperature alteration. Their inherent limit is that each thermocouple can test temperature only at the contact point of the surface. The contact point has an important role to view when temperature is evaluated, as larger contact areas can detect temperature elevation more precisely ${ }^{(7)}$. The thermocouples used in this study, were provide a larger contact surface between the root dentin and the thermocouple sensor specifically, permitting contact throughout the experiment. Instrumentation can be viewd the high factor in heat generation procedures in the field ${ }^{(5,7)}$. The debridement had a range lower than $10{ }^{\circ} \mathrm{C}$, which is considered the critical temperature for tissue damage; in general regardless of type of motion ${ }^{(8)}$.
The rotation motion had higher temperature than reciprocation and this might be continuous contact to canal wall rather than reciprocating interrupted motion and friction, however, additional studies should be performed to assess factors at the macro- and microscopic levels, studying the characteristics of root dentin, periodontal ligament and alveolar bone cells to minimize the factors that may lead to immediate or mediate endodontic failures. The first tested hypothesis was accepted, as the temperature rise generated during endodontic treatment was different among the two different instrumentation motions ${ }^{(7-8)}$.

\section{CONCLUSION}

The different types of preparation motions during root canal instrumentation had effect on the different temperature alteration on eternal surfaces.

\section{REFERENCES}

1. Hulsman M, Peters OA, Dummer PMH. Mechanical preparation of roots canals: shaping goals, techniques and means. Endod Top 2005; 10:3076.

2. Mousavi SA, Kargar-Dehnavi V, Mousavi SA. A novel approach to determine the effect of irrigation on temperature and failure of $\mathrm{Ni}-\mathrm{Ti}$ 
endodontic rotary files. Dent Res J 2012; 9:281287.

3. Hardie EM. Further studies on heat generation during obturation techniques involving thermally softened gutta-percha. Int Endod J 1987; 20:122-127.

4. Obermayr G, Walton RE, Leary JM, Krell KV. Vertical root fracture and relative deformation during obturation and post cementation. J Prosthet Dent 1991; 66:181-187.

5. Saunders EM, Saunders WP. The heat generated on the external root surface during post space preparation. Int Endod J 1989; 22:169-173.
6. Tjan AHL, Abatte MF. Temperature rise at root surface during post space preparation. J Prosthet Dent 1993; 69:41-45.

7. Mc Cullagh JJP, Setchell DJ, Gulabivala K, Hussey DL, Biogioni P, Lamey PJ, et al.. A comparison of thermocouple and infrared thermographic analysis of temperature rise on the root surface during continuous wave condensation technique. Int Endod J 2000; 3:326-332.

8. Eriksson AR, Albrektsson T. Temperature threshold levels for heat induced bone injury: a vital microscopic study in the rabbit. J Prosthet Dent 1983

كوّرينى تيرهجى ده ديمه نامادهكرينى ده كهنالينى راديويه يان بى فاكهرتينى فَيرسا نهرازيَبوّنى

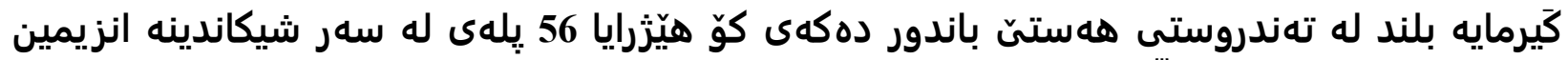

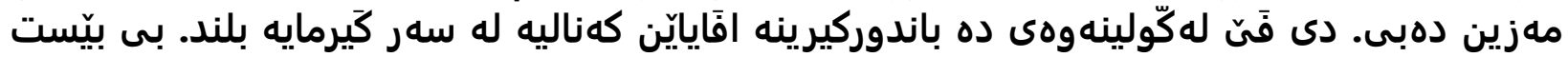

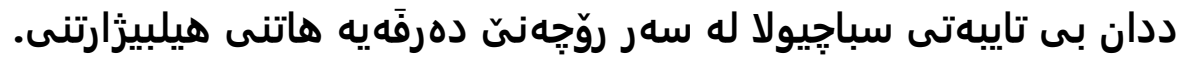

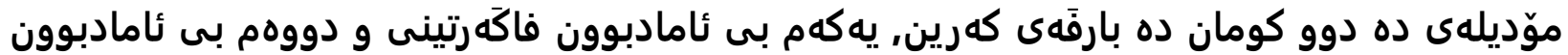

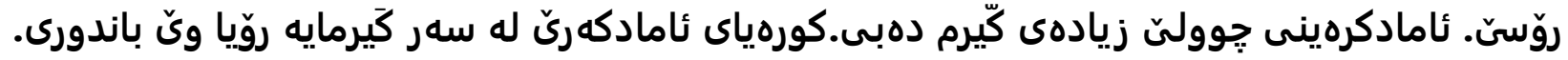

التغيير الحراري أثناء تحضير قنوات الجذر بواسطة الدوران مقابل التبادل

أن أرتفاع درجة الحرارة يؤثر على صحة العظام لذلك الارتفاع الذائد عن 56 درجة مئوية يؤدي الى

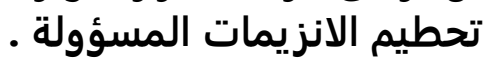

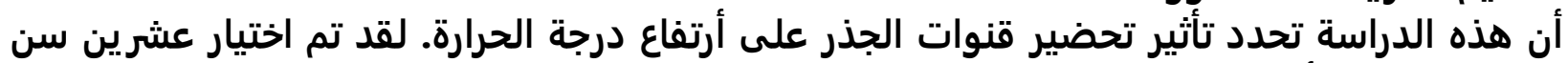

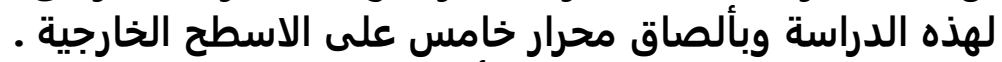
قد قيس ارتفاع درجة الحرارة أثناء تحضير الجذر الدراء وقسمت النماذج الى مجموعتين لكل منها 10

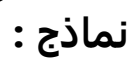

المجموعة الاولى حضرت بواسطة التحضير الدوراني أما المجموعة الثانية فحضرت المرانير بالطريقة

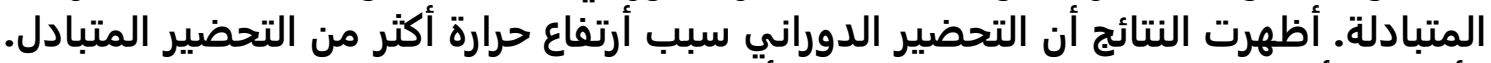

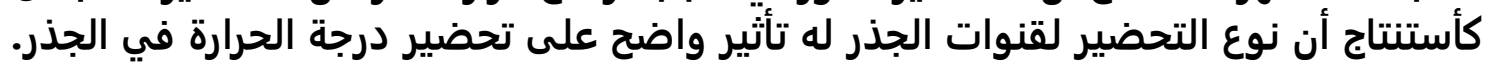

